\title{
Availability and Teachers' Use of Instructional Materials and Resources in the Implementation of Social Studies in Junior Secondary Schools in Edo State, Nigeria
}

\author{
Dr (Mrs) E.O. Okobia \\ Department of Educational Psychology and Curriculum Studies Faculty of Education \\ University of Benin, Benin City, Edo State, Nigeria \\ E-mail: obyokobia@yahoo.com
}

Received: August 19, 2011

Accepted: October 21, 2011

Published: December 1, 2011

doi:10.5539/res.v3n2p90

URL: http://dx.doi.org/10.5539/res.v3n2p90

\begin{abstract}
Social studies is a core subject offered in the junior secondary school educational system. This study is designed to assess the availability and teachers' use of instructional materials and resources in the implementation of junior secondary school social studies curriculum in Edo state. Three research questions were raised and one hypothesis was formulated. A sample of fifty social studies teachers were randomly selected from fifty junior secondary schools in five local government areas of Edo State. Data analysis was carried out using t-test for the hypothesis and simple percentages for questions one and two. The results showed that instructional materials and resources available were grossly inadequate. It was also observed that there was no difference in the use of instructional materials between specialist social studies teachers and non-specialist teachers. It is therefore recommended that instructional materials and resources be made available for the teaching of social studies.
\end{abstract}

Keywords: Instructional materials, Resources, Implementation, Social studies, Nigeria

\section{Introduction}

Teaching at any level requires that the students be exposed to some form of simulation. Adekunle (2008) noted that teaching resources in social studies means anything that can assist the teacher in promoting teaching and learning. When the students are given the chance to learn through more senses than one, they can learn faster and easier. The use of instructional materials provides the teacher with interesting and compelling platforms for conveying information since they motivate learners to learn more. Furthermore the teacher is assisted in overcoming physical difficulties that could have hindered his effective presentation of a given topic. Larson (2001) quoted Lane (1994) who noted that the use of electronically mediated instruction to duplicate the traditional face to face classroom has resulted in a shift from teacher- to student-centred classes. In this situation the responsibility for learning is shifted to the students. The teacher facilitates the learning by acting as a coach, resource guide and companion in learning. The use of instructional materials does not only encourage teachers and students to work collaboratively but also results in more cooperative learning activities among the students.

Ikerionwu (2000) refers to instructional materials as objects or devices which help the teacher to make learning meaningful to the learners. Similarly, Ezegbe (1994) classified them into two as visual materials, made up of reading and non-reading materials and audiovisual materials comprising electrically operated and non-electrically operated materials. Social studies is a subject that depends on the use of a number of resources. Osakwe and Itedjere (1993) summarized these resources as textual like books, audio-visual and human resources. They stated that these resources are either used individually or collectively in any meaningful social studies teaching and learning situation.

The purpose of instructional materials is to promote efficiency of education by improving the quality of teaching and learning. Incorporating these tools and materials present, support and reinforces teaching. According to Aduwa-Ogiegbaen and Imogie (2005) these materials and resources including audio tape recorders, video tape recorders, slide projectors, opaque projectors, over head projectors, still pictures, programmed instruction, filmstrips, maps, chart, graphs and many more offer a variety of learning experiences individually or in combination to meet different teaching and learning experiences. 
Other investigators including Jimoh (2009), Yeager (2000), Nwanyanwu (1999), Bozimo (1992) and Ogbondah (2008) have similarly emphasized the importance of instructional materials and resources in the effective delivery of social studies lessons in secondary schools. These views have been corroborated by international investigators including Bolick, Berson, Coutts and Heinecke (2003), Killen (2006), Kadzera (2006), Abdo and semela (2010), Jotia and Matlale (2011) and Dahar and Faize (2011). Bolick, Berson, Coutts and Heinecke (2003) observed that while some educators are fascinated by the potential of instructional materials in enhancing teaching and learning, other teachers lagged behind in using instructional materials to teach. However, achieving these laudable goals of conscientious utilization of instructional materials and resources in social studies teaching and learning has been very challenging in developing countries such as Nigeria. As noted by Garuba (2003), the Nigerian teacher operates from a deficient environment where teaching and learning is seriously impoverished particularly in the rural set up. And even in the urban areas only few schools are connected to the national grid while virtually all the rural schools do not enjoy basic facilities like pipe borne water and electricity.

Since the inception of the National Junior Secondary School Social Studies Curriculum in Nigeria, few studies have been devoted to evaluating the availability and utilization of instructional materials and resources in the teaching of social studies in the Junior Secondary Schools in Edo State of Nigeria. At the threshold of the new millennium, social studies teachers face both old and new challenges and need to evolve strategies to engage learners in activities that are active, meaningful and challenging. This study seeks to fill the void through addressing the following research questions:

(1) Are instructional materials and resources available for the teaching of social studies in the junior secondary schools in Edo State?

(2) How often do social studies teachers use instructional materials to teach social studies?

(3) To what extent does area of specialization of social studies teachers influence their use of instructional materials and resources? These research questions stem from the hypotheses that instructional materials and resources for the teaching of social studies in the junior secondary schools in Edo State are inadequate and that teachers' area of specialization will not significantly influence their use of instructional materials and resources during social studies classroom instruction.

\section{Methodology}

The study adopted survey research design utilizing observation of actual social studies classrooms. This was to assess the availability of instructional materials and teachers' use of instructional materials. The population consisted of fifty teachers sampled from fifty junior secondary schools in five local government areas of Edo State. The sampling was carried out through simple random technique. Ten teachers were selected from ten schools in each of the local government area. These teachers were observed teaching social studies at different occasions for twelve weeks.

The instrument used in this study was the classroom observational schedule which was divided into two sections A and B. Section A focused on the demographic information while section B dealt with availability of instructional materials and the frequency of use of instructional materials by social studies teachers. The content validity of the instrument was established through the use of three social studies experts. To determine the reliability of the classroom observational schedule, an inter-rater reliability was carried out obtaining a reliability of ( $\mathrm{r}-0.75)$. Then an observational schedule and a rating scale developed for this purpose was used for the classroom observation. Social studies teachers were observed teaching social studies at different occasions for twelve weeks.

Instructional materials and resources itemized were rated. The essence is to find out whether these materials were available in the schools and the frequency of use by social studies teachers. Statistics such as frequency count and percentages were used to analyze data for research questions 1 and 2 . The influence of teachers' area of specialization on the use of instructional materials and resources was assessed using Likert scale questions in which teachers were rated on the frequency of their use of different instructional materials. The likert scale scores were computed for each teacher and the scores were aggregated to obtain the overall score for each teacher. The data was then used to compute the mean scores of specialist and non-specialist social studies teachers. The differences in the mean scores were evaluated using t-test. 


\section{Analyses and Results}

The study was designed to evaluate the availability of instructional materials and resources for the teaching of social studies in junior secondary schools in Edo State of Nigeria. Fifty teachers of social studies in junior secondary schools were recruited from 50 junior secondary schools in the State.

\subsection{Question 1: Are instructional materials and resources available for the teaching of social studies}

Table 1 shows the distribution of the availability of instructional materials for Social Studies classroom instruction in the 50 junior classrooms observed. The most available instructional materials included textbooks $(100 \%)$, chalkboard $(100 \%)$, maps and atlases $(48 \%)$. The next most available materials included display boards $(20 \%)$ graphs and charts $(20 \%)$ and globes $(18 \%)$. The data showed that other instructional materials for teaching social studies were grossly lacking for example, radio tapes $(0 \%)$ over head transparencies $(0 \%)$ video tapes $(0 \%)$ computer $(0 \%)$ as shown in the Table 1 , fig 1.

\subsection{Question 2: How often do social studies teachers use instructional materials to teach social studies}

Fifty social studies teachers sampled from the junior secondary schools were observed at different occasions to find out how often they used instructional materials to teach Social Studies in their classrooms. A summary of frequency of use of instructional materials is presented in Table 2. From the Table, textbooks and chalkboards are the most commonly used in social studies lessons, for textbooks, five times a week in only two schools (4\%), four times a week in one school (2\%) and three times a week in forty-seven schools (94\%). Chalkboards were used five times a week in only two schools (4\%) and three times a week in forty eight schools $(96 \%)$. Other instructional materials including radio tapes, overhead transparencies, television sets and computers were sparingly used in majority of the classrooms. Video recorders and overhead projectors were not used at all during social studies classroom instruction. The frequency of use of other instructional materials is shown in the table. Use of technology is almost non-existent.

\subsection{Hypothesis 1 teachers' area of specialization did not significantly influence their use of instructional materials and resources}

Of the 50 Social studies teaches that participated, 15 were specialists and 35 were non-specialists (Table3.). The scores of the specialists and non-specialist Social Studies teachers on the use of instructional materials were similar. Mean score for specialists Social Studies teachers was $0.20(\mathrm{sd}=0.561)$ and mean score for non-specialist Social studies teachers was $0.20(\mathrm{sd}=0.584)$. There was no significant difference when the scores on use of instructional materials by the specialist and non-specialist Social Studies teachers were compared using $\mathrm{t}$-test $(\mathrm{t}=0.000, \mathrm{p}=1.000)$. This means that specialization did not significantly influence teachers' use of instructional materials.

\section{Discussion}

The result of this study on observation of classrooms revealed that most instructional materials and resources are not available in the schools for the teaching of social studies. The most available instructional materials are textbooks and chalkboards. These were predominantly used in the classrooms. Other instructional materials such as charts, graphs, diagrams, cartoons, posters, pictures, maps/atlases which are locally available and inexpensive are not provided. These are completely neglected in the social studies teaching process. Audio-visual materials like television, computers, overhead transparencies, video recorders are not just there at all. This is observed in both urban and rural schools irrespective of the fact that audio-visual materials are very useful in teaching social studies. Most times social studies teachers relied on only social studies textbooks where available.

The above summary captures the deplorable state of social studies teaching and learning experiences in most junior secondary schools in Edo State. It portrays the complete neglect of the rudiments enunciated in the National Guidelines for the successful implementation of the junior secondary school Social studies curriculum. It is a verdict of failure on the part of all stakeholders charged with the responsibility for the implementation of the curriculum. The heavy reliance on a single textbook like "Nigerian secondary school Social Studies Project" cannot achieve results.

These findings are corroborated with the reports of several investigators that have examined the use of instructional materials in social studies classroom in some states of Nigeria (Arisi, 1998; Ekpo, 2001; Inyang-Abia, 1992; Jimoh, 2009; Garuba, 2003). Arisi (1998) noted that more than 90\% of the schools she investigated in Edo State lacked instructional materials. In a comprehensive review of strategies for managing school curriculum, Ekpo (2001), observed that of all the problems plaguing education in Nigeria, the most intractable is the dearth of relevant teaching resources. Similarly, Inyang-Abia (1992) noted the non-availability of instructional materials in most schools in Akwa Ibom State. Similarly, Jimoh (2009) investigated the use of 
instructional materials in the teaching of social studies in Secondary Schools in Kabba Bunu Local Government Area of Kogi State of Nigeria. Results of his study indicated minimal use of instructional materials in the teaching of social studies in most schools in the area. Most teachers depended mostly on textbooks and chalkboards as instructional materials while other relevant instructional materials such as maps and charts, overhead projectors, televisions, cartoons, computers and pictures etc were sparingly used. The study also noted other problems associated with the use of instructional materials including cost of manufacturing and maintenance of instructional materials, reluctance of teachers to improvise, lack of social studies resource rooms for storage of instructional materials, limited time allocated to social studies in the school time table and lack of skills on the part of the teachers in the use of instructional materials. In a comprehensive evaluation of the utilization of information technology in the teaching of social studies, Garuba (2003) noted that computer literacy was extremely low among social studies teachers. The experiences in the utilization of instructional materials in social studies classroom instruction are not different from the reports of various investigators on the use of instructional materials in other subject areas (Ogbondah, 2008). In an appraisal of the utilization of instructional materials in the education of Migrant Fishermen's children in Rivers State of Nigeria, Ogbondah (2008) reported shortage of instructional materials in the schools. He noted that there was significant relationship between availability and adequate utilization of instructional materials and effective implementation of Migrant Fishermen's children education programme in Rivers State of Nigeria.

The findings of limited availability and poor utilization of instructional materials in the teaching of social studies in most Nigerian schools have been corroborated by the reports of other investigators both within Africa [Jotia and Matlale (2011), Abdo and Semela (2010), Kadzera (2006)] and beyond [Dahar and Faize (2011)]. In an evaluation of the use of instructional materials in the teaching of social studies in primary schools in Botswana, Jotia and Matlale (2011) found that teachers' use of instructional materials was very inadequate and this invariably had impact on pupil's performance in primary school leaving certificate examination. Similarly, Abdo and Semela (2010) reported low use of instructional media in primary schools of Gedeo zone in Southern Ethiopia. In Malawi, Kadzera (2006) noted that there was infrequent use of higher order instructional technologies such as overhead projectors, videos and computers in Teacher Training Colleges. The author identified lack of creative thinking and initiative on the part of the teachers as factors responsible for failure to use the locally available instructional resources in their teaching. Dahar and Faize (2011) noted that there was great deficiency in the use of instructional materials in schools in Punjab district in Pakistan.

The strategic and vital role of instructional materials and resources in the successful implementation of the National Junior Secondary Schools Socials Studies Curriculum cannot be overemphasized. As noted by Jimoh (2009), the use of instructional materials is a sine qua non in effecting behavior change in learners in every field especially social studies. Advances in technology have brought instructional materials especially the projected and electronic materials to the forefront as the most radical tools of globalization and social development which have affected the classroom teaching/learning situation positively. Jimoh opined that new technological breakthroughs such as networked and non-networked, projected and non-projected, visual, auditory, audio-visual electronic materials are important landmark in knowledge transfer. With them both teaching and learning become very pleasant experiences and less stressful. Similar views were emphasized by Yeager (2000) who reported that the U.S. National Council for Social Studies (NCSS) task force in 1993 identified five key characteristics of ideal social studies teaching and learning. She stated that social studies teaching is powerful when it is meaningful, integrative, value-based, challenging and active.

Teaching is not complete until knowledge has been successfully transferred which in most cases may not just be tied to teacher effectiveness or teaching skill but the instructional materials used in the learning process. According to Jimoh (2009), ordinary words or verbalization has been found to be inadequate for effective teaching. Instructional materials serve as a channel through which message, information, ideas and knowledge are disseminated more easily. They can therefore be manipulated, seen, heard, felt or talked about. These materials facilitate activities and they are any thing or anybody the teacher turns to for help in learning process. Bozimo (2002) advised that there are ever increasing numbers of audio and visual materials available to schools. The teachers should take advantage of the opportunities to procure excellent films and recordings covering a wide range of subject matters in social studies curriculum. While acknowledging that the issue of instructional materials may not be easily resolved, it is important to remark that teachers should not use lack of instructional materials as an excuse not to teach well (Killen, 2008). It should be recognized that alternatives are out there and teachers should refrain from depending solely on the local education council for the provision of ready made materials. They should reach out for local materials in the environment and improvise whenever the need arises. 
All these views on the strategic role of instructional materials and resources in the effective delivery of social studies lessons were succinctly captured by Nwanyanwu (1999) who summarized the purposes of using instructional materials in the teaching of socials studies to include (a) Making the subject matter more real, (b) Explicating difficult concepts, (c) Making the learners to experience what is being learnt, (d) Helping to fire the imagination of the learners, (e) Preventing misconceptions, (f) Preventing boredom and (g) Making learning interesting.

This study also revealed that area of specialization of teachers did not significantly influence teachers' use of instructional materials and resources; this is rather disturbing because specialization in Social Studies education is a key factor in successful curriculum implementation. For this study however, certain reasons can be postulated to explain this discouraging finding. Firstly specialist Social Studies teachers who are supposed to form the life wire of Social Studies curriculum implementation are hard to find in most schools. Results of this study showed that a disproportionately low percentage of 30\% are specialist Social Studies teachers. The bulk of teachers in charge of the implementation of Social Studies are non-specialists. It is also noted that majority of the specialist Social Studies teachers are holders of Nigerian Certificate in Education (NCE) and therefore may not have been well grounded in the skills of curriculum implementation. Many teachers did not see the use of instructional materials as necessary but as stumbling block and a waste of time. This assertion was confirmed in the findings of Mezieobi (2003) and Nwalado (2007) who observed that most non-social studies specialists do not use instructional materials in their teaching/learning process. In addition, it was observed that teachers are not being supervised by head teachers or principals and therefore lack of commitment by teachers.

\section{Conclusion and Recommendations}

Educational attainment depends a lot on the quality of teaching. The findings of this study revealed that there are lack of instructional materials and resources for the implementation of Social Studies curriculum in the junior secondary schools in Edo State of Nigeria. Most teachers do not use instructional materials to teach. The lack of necessary instructional materials and resources reduces the students to mere passive participants in the learning process. Consequently, there is erosion of enthusiasm in the teaching/learning process by both teachers and students. The following recommendations are made based on the above findings. (1) There is need for all stakeholders including the Federal, State and Local Governments and the Private sector to contribute financially and materially in the provision of instructional materials and resources for the teaching of social studies in the junior secondary schools in Edo State. (2) There is urgent need for the organization of regular workshops/seminars for social studies teachers, head teachers and principals on the importance and current developments and progress in the use of instructional materials and resources in social studies teaching in the junior secondary schools. (3) School Heads, Principals and officials of the Ministry of Education should ensure regular supervision to enhance effective use of instructional materials and resources in the teaching of Social studies in the junior secondary schools.

\section{References}

Abdo, M. and Semela, T. (2010). Teachers of poor communities: The tale of instructional media in primary schools of Gedeo zone, Southern Ethiopia. Australian Journal of Teacher Education, 35 (7), 78-92.

Aduwa-Ogiegbaen S. O. and Imogie, A. I. (2005). Instructional communication and technology in higher education Ibadan. Stirling Hordon publishers (Nig) Ltd.

Arisi, R. O. (1998). The use of instructional materials by Social Studies teachers in secondary schools in Oredo local government area of Edo State. Journal of Social Studies, 1 (1), 76.

Bolick, C., Benson, M, M., Coutts, C and Heinecke, W. (2003). Technology applications in Social Studies teacher education. A survey of Social Studies methods. Contemporary issues in technology and teacher education 3 (3). [Online] Available: http//www.citejournal.org./vol3/iss3/social studies/article/.cfm

Bozimo, G. (2002). Social studies theories and perspectives. Onitsha. Outrite publishers.

Dahar, M.A. and Faize, F.A. (2011). Effect of the availability and the use of instructional materials on academic performance of students in Punjab (Pakistan). Middle Eastern Finance and Economics Issue 11.

Ekpo, C. M. (2001). Strategies for managing school curriculum and resources for national building. Nigerian journal of curriculum and instruction, 10(1), 51.

Ezegbe, M. O. (1994). Social Studies curriculum and instruction in Joof, G.W and Amadi, H.C (Eds). Social Studies in schools: teaching methods, techniques, approaches and perspectives. Onitsha, Nigeria, Outrite publishers. 
Garuba, A. (2003). Teachers and teaching in Nigeria. A paper presented in $11^{\text {th }}$ biennial conference of international study association for teachers and teaching (ISATT) Leiden Netherlands [Online] Available: http://wwwlisatt.org.

Ikerionwu, J. C. (2000). Importance of aids and resources in classroom teaching. In Oyeneyin, A.M. (ed). Perspectives of Classroom Teaching. Abuja: Martmonic Investment Ltd.

Inyang-Abia, M. E. (1992). Cultural dimension in curriculum materials: A study of longman Social Studies series for junior secondary classes. Nigerian journal of Social Studies review (1), $96-103$.

Jimoh, M. E. (2009). The use of instructional materials in teaching Social Studies at the secondary schools of Kabba Bunu Local Government area of Kogi State [Online] Available: http://www.docstoc.com

Jotia, A. L. and Matlale, O. J. (2011). Use of instructional materials in social studies: Impact on students' performance in primary school leaving certificate examinations in Botswana. European Journal of Educational Studies, 3(1), 111-122.

Kadzera, C. M. (2006). Use of instructional technologies in Teacher Training Colleges in Malawi. Unpublished PhD Dissertation, Virginia Polytechnic Institute and State University, USA.

Killen, R. (2006). Effective teaching strategies: Lesson from Research and Practice (4 ${ }^{\text {th }}$ ed.) New Castle: Thompson.

Larson, T. D. A. (2001). comparison of fifth grade children receiving both traditional and technology based means of instruction in Social Studies. Unpublished master dissertation, Johnson Bible College Knoxville, USA.

Mezieobi, D. I. (2003). Effect of instructional materials on the teaching Social Studies in secondary school in Edo State. Unpublished M.Ed thesis Delta State University, Abraka.

Nwalado, E. N. (2007). Teacher factor in the implementation of Social Studies programmes in Delta State secondary schools. Unpublished M.Ed thesis, Delta State University, Abraka.

Nwanyanwu, O. J. (1999). Current trends in Social Studies instruction. Abeokuta, GOAD Educational publishers.

Ogbondah, L. (2008). An appraisal of instructional materials used to educate Migrant Fishermen's children in Rivers State, Nigeria. International Journal of Scientific Research in Education, 1(1), 13-25.

Osakwe, E and Itedjere, P. (1993). Social Studies for tertiary students in Nigeria. Enugu: New age publishers.

Yeager, E. A. (2000). Thoughts on wise practice in the teaching of Social Studies. The official Journal of National council of the Social Studies. 64(6).

Table 1. Availability of instructional materials in junior secondary schools observed $(n=50)$

\begin{tabular}{|l|c|c|c|c|}
\hline Items & Schools where items are Available & $\%$ & Schools where items not available & $\%$ \\
\hline Pictures & 22 & 44 & 28 & 56 \\
\hline Textbooks & 50 & 100 & 0 & 0 \\
\hline Maps and Atlases & 24 & 48 & 26 & 52 \\
\hline Models & 2 & 4 & 48 & 96 \\
\hline Radio Tapes & 0 & 0 & 50 & 100 \\
\hline New Bulletins \& Posters & 4 & 8 & 46 & 92 \\
\hline Newspapers \& magazines & 4 & 8 & 46 & 92 \\
\hline Overhead Transparencies & 0 & 0 & 50 & 100 \\
\hline Display Boards & 10 & 20 & 40 & 80 \\
\hline Globes & 9 & 18 & 41 & 82 \\
\hline Graphs and Charts & 10 & 20 & 40 & 80 \\
\hline Films strips & 1 & 2 & 49 & 98 \\
\hline Radio sets & 0 & 0 & 50 & 100 \\
\hline Television sets & 1 & 2 & 49 & 98 \\
\hline Computer & 0 & 0 & 50 & 100 \\
\hline Video Recorders & 0 & 0 & 50 & 100 \\
\hline Overhead Projector & 0 & 100 & 50 & 100 \\
\hline Chalkboards & 50 & & 0 & 0 \\
\hline
\end{tabular}


Table 2. Frequency of use of instructional materials in social studies lessons (number of times and percentages that teachers use instructional materials per week according to the time table)

\begin{tabular}{|c|c|c|c|c|c|c|c|c|c|c|c|c|}
\hline \multirow[t]{3}{*}{$\begin{array}{l}\text { Instructional } \\
\text { Materials }\end{array}$} & \multicolumn{12}{|c|}{$\begin{array}{l}\text { Frequency of use of instructional materials } \\
\mathrm{n}=50 \text { (schools) }\end{array}$} \\
\hline & \multicolumn{2}{|c|}{ Not at all } & \multicolumn{2}{|c|}{$\begin{array}{l}\text { Once a } \\
\text { wk }\end{array}$} & \multicolumn{2}{|c|}{$\begin{array}{ll}\text { Twice } & a \\
\text { wk } & \end{array}$} & \multicolumn{2}{|c|}{$\begin{array}{l}\text { Three times a } \\
\text { wk }\end{array}$} & \multicolumn{2}{|c|}{$\begin{array}{l}\text { Four times a } \\
\text { wk }\end{array}$} & \multicolumn{2}{|c|}{$\begin{array}{l}\text { Five times a } \\
\text { wk }\end{array}$} \\
\hline & $\mathrm{F}$ & $\%$ & $\mathrm{~F}$ & $\%$ & $\mathrm{~F}$ & $\%$ & $\mathrm{~F}$ & $\%$ & $\mathrm{~F}$ & $\%$ & $\mathrm{~F}$ & $\%$ \\
\hline Pictures & 29 & 58 & 6 & 12 & 13 & 12 & 2 & 4 & 0 & 0 & 0 & 0 \\
\hline Textbooks & 0 & 0 & 0 & 0 & 0 & 0 & 47 & 94 & 1 & 2 & 2 & 4 \\
\hline Maps and Atlases & 26 & 52 & 13 & 26 & 11 & 22 & 0 & 0 & 0 & 0 & 0 & 0 \\
\hline Models & 48 & 96 & 2 & 4 & 0 & 0 & 0 & 0 & 0 & 0 & 0 & 0 \\
\hline Radio Tapes & 50 & 100 & 0 & 0 & 0 & 0 & 0 & 0 & 0 & 0 & 0 & 0 \\
\hline $\begin{array}{l}\text { New Bulletins and } \\
\text { Posters }\end{array}$ & 46 & 92 & 3 & 6 & 1 & 2 & 0 & 0 & 0 & 0 & 0 & 0 \\
\hline $\begin{array}{l}\text { Newspapers and } \\
\text { magazines }\end{array}$ & 46 & 92 & 4 & 8 & 0 & 0 & 0 & 0 & 0 & 0 & 0 & 0 \\
\hline $\begin{array}{l}\text { Overhead } \\
\text { Transparencies }\end{array}$ & 50 & 100 & 0 & 0 & 0 & 0 & 0 & 0 & 0 & 0 & 0 & 0 \\
\hline Display Boards & 41 & 82 & 5 & 10 & 4 & 8 & 0 & 0 & 0 & 0 & 0 & 0 \\
\hline Globes & 41 & 82 & 6 & 12 & 3 & 6 & 0 & 0 & 0 & 0 & 0 & 0 \\
\hline Graphs and Charts & 40 & 80 & 4 & 8 & 6 & 12 & 0 & 0 & 0 & 0 & 0 & 0 \\
\hline Films strips & 49 & 98 & 1 & 0 & 0 & 0 & 0 & 0 & 0 & 0 & 0 & 0 \\
\hline Radio sets & 49 & 98 & 1 & 0 & 0 & 0 & 0 & 0 & 0 & 0 & 0 & 0 \\
\hline Television sets & 50 & 100 & 0 & 0 & 0 & 0 & 0 & 0 & 0 & 0 & 0 & 0 \\
\hline Computer & 50 & 100 & 0 & 0 & 0 & 0 & 0 & 0 & 0 & 0 & 0 & 0 \\
\hline Video Recorders & 50 & 100 & 0 & 0 & 0 & 0 & 0 & 0 & 0 & 0 & 0 & 0 \\
\hline Overhead Projector & 50 & 100 & 0 & 0 & 0 & 0 & 0 & 0 & 0 & 0 & 0 & 0 \\
\hline Chalkboards & 0 & 0 & 0 & 0 & 0 & 0 & 48 & 96 & 0 & 0 & 2 & 4 \\
\hline
\end{tabular}

Table 3. Influence of specialization on the use of instructional materials and resources

\begin{tabular}{|l|l|l|l|l|l|}
\hline Area of specialization & $\mathrm{N}$ & $\begin{array}{l}\text { Mean } \\
\mathrm{x}\end{array}$ & $\mathrm{Sd}$ & $\mathrm{t}$ & $\mathrm{p}$ \\
\hline Specialists & 15 & 0.20 & 0.561 & \multirow{2}{*}{0.000} & \multirow{2}{*}{1.000} \\
\hline & & & & & \\
\hline Non-specialists & 35 & 0.20 & 0.584 & & \\
\hline
\end{tabular}

$\alpha=0.05$ 


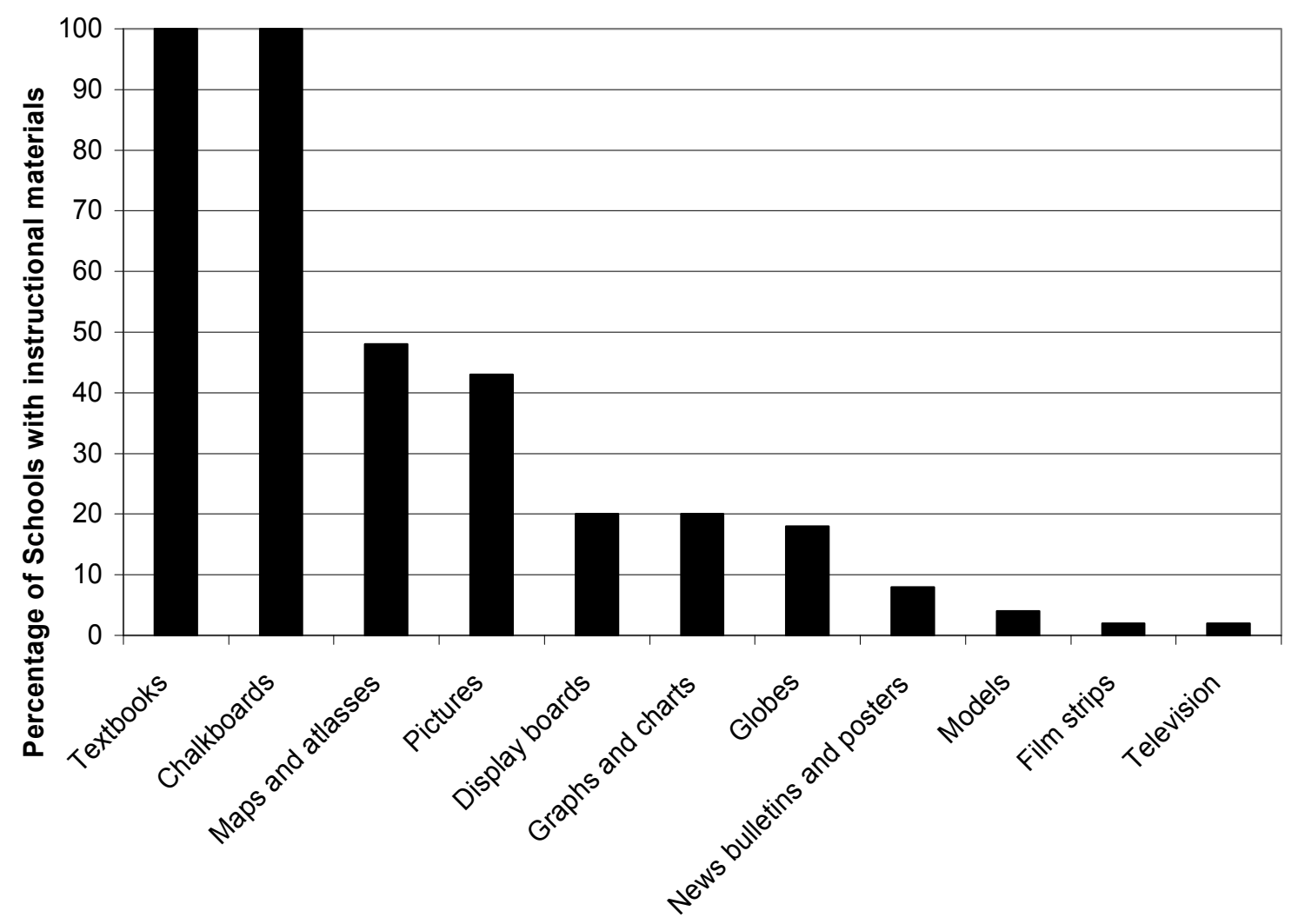

Figure 1. Availability of instructional materials 